\title{
Article
}

\section{Handbook of research on management ideas and panaceas: adaptation and context [Book Review]}

Slater, Ruth Elizabeth

Available at http://clok.uclan.ac.uk/23325/

Slater, Ruth Elizabeth ORCID: 0000-0003-0302-5919 (2020) Handbook of research on management ideas and panaceas: adaptation and context [Book Review]. Management Learning, 51 (2). pp. 241-244. ISSN 1350-5076

It is advisable to refer to the publisher's version if you intend to cite from the work. http://dx.doi.org/10.1177/1350507618780416

For more information about UCLan's research in this area go to http://www.uclan.ac.uk/researchgroups/ and search for < name of research Group>.

For information about Research generally at UCLan please go to http://www.uclan.ac.uk/research/

All outputs in CLoK are protected by Intellectual Property Rights law, including Copyright law. Copyright, IPR and Moral Rights for the works on this site are retained by the individual authors and/or other copyright owners. Terms and conditions for use of this material are defined in the policies page.

\section{CLoK}

Central Lancashire online Knowledge www.clok.uclan.ac.uk

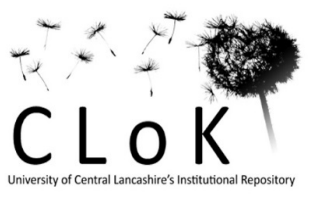




\section{Book review: Örtenblad A (ed) (2015) Handbook of Research on Management Ideas and Panaceas: Adaptation and Context, Cheltenham, UK: Edward Elgar Publishing, 508 pages, ISBN 9781 783475599 (HBK)}

I am interested in organisational practices, but I have long questioned the adoption of packaged management knowledge in the field of HRM and HRD purporting to lead to performance. I was excited, therefore, at the prospect of reviewing this book and even more reassured to learn from this collection that others were also interested in this question:

'why are managers inclined (and increasingly so) to consume management knowledge?' (Mazza and Strandgaard 2015: 349).

This collection of contributions concerns management knowledge, and how it is packaged into consumable commodities and used. There are a number of different terms for this phenomenon, however, for the purpose of appreciating this collection, a consumable commodity is the management panacea, or 'fashionable management idea' (FMI), a term favoured by the editor, Anders Örtenblad, and his collaborators. There are also different meanings attributed to the FMI, however, the kernel of any practice which may be labelled as an FMl is that it is:

'...fit-for-all (...) if it provides an all-healing practical remedy which makes producers, diffusers, adopters and users happy' (Mazza and Strandgaard Pedersen 2016: 338).

An additional attribution of the FMI is that it is a choice:

'...about what should be done and reduce risks associated with how things should be done to a few manageable fundamentals' (Whittle 2015: 183).

Management knowledge packaged in FMI has tended to be either viewed as innovation (following Rogers 1962) or as 'fads and fashions' (Abrahamson 1996) and steeped in symbolism. Therefore, whilst acknowledging FMI are discourses, the role of the manager in adopting and implementing them has tended to be viewed as passive and over willing; the adoption an over-simplification of practice as managers seek to allay anxiety in fraught periods by showing to the workforce that there is a remedy that can be followed. This collection, however, appears to steer a course through, on the one hand, the naysayers who criticise the tendency for managers and organisations to adopt an FMl as originally packaged and those, on the other, who see something of value, whatever the practice and managers' motivations.

The main proposition in this collection argues that there should be more rational and considered thinking in the adoption of FMI, and contextualised adaptation. The collection divides into three parts, with Part 1 serving to provide background and an introduction to the topic. In Chapter 1, the editor, Anders Örtenblad, names some of the discourses and explains how they have been taken to be FMIs. $\mathrm{He}$ also explains the various constructions and names given to the practices which are under discussion; this serves to provide a reader with a grounding in the subject of 'fads', 'fashions', and 'panaceas'. There is a useful, if complex, checklist to contextualise, adopt and adapt a management panacea. 
Part II deals with an important idea central to the aim of the book, and that is the contextualisation of the FMI. By this point, the reader is fully aware of what an FMI is, and more importantly, what contextualisation is, how it takes place, and its association with theories on the translation, travels and diffusion of ideas. Part II discusses four specific 'panaceas' - pay secrecy, Japanese management, social cognitive theory, and, of great interest to me, Strategic Human Resource Management. The overall thrust of Part II, therefore, is that these are all discourses and practices which have had wide diffusion and widespread adoption but which would benefit from contextualisation, rather than wholesale adoption.

Part III, described by Örtenblad (2015:17) as the "heart" of the collection, comprises three sections and is an exhortation to readers to scrutinise the ideas and promises implied within FMls. The three sections provide illustrations of how three actor groups - researchers, managers, and teachers and students in higher education - have contextualised FMls, providing examples of contexts where FMIs have been 'planted' and how they have been adapted.

Part IV offers more than a summarised conclusion - it offers reflections on the premise of the collection and a counter view. For example, Rüling (2015) argues that panaceas as discourses can become a lens through which the thinking manager can "...reflect upon and critically review their own world views and interpretations" (Rüling 2015: 438). In proposing this sensemaking perspective, Rüling questions the extent to which there can be rational thinking in the adoption, adaptation and contextualisation of FMIs. The editor, Anders Örtenblad, concludes the book by offering suggestions for more insight-led adaptations and contextualisation.

The collection is replete with ideas for various approaches to the implementation and contextualisation of FMI and panaceas and there are many highlights. For example, the model proposed in Chapter 1, coupled with its development in Chapter 12, exploring the significance of stakeholder outcomes during the adoption of an FMI. Some of the chapters readily acknowledge that FMls do evolve in implementation suggesting some managerial agency. However, one of the most interesting discussions is that explored by Mazza and Strandgaard Pedersen (2015: 347) concerning why an FMI is perceived to be crucial in the first place. These authors answer this by reference to Girard's 'triangular desire' (1988), in which the three points of the triangle are the actor, the actor's role model and the role model's behaviour. The point being, that the actor is actively selecting the choices that have been or are assumed would be taken by the role model.

Another intriguing chapter in the collection is that which introduces Part III, on The art of constructive criticism (Ohlsson and Rombach 2015: 149) in which the contributors remind academics who teach about FMI and practitioners who implement them that it is acceptable to examine and critique the recipe in front of them.

It is, however, the final section of Part III, which perhaps would be more significant for this readership. Section C of Part III sees the topic situated within HE and the business/management school. This section offers some pedagogic handles for educators as they help students steer a course around the plethora of FMls which tend to be the building blocks of the standard curriculum. Section C of Part III is where I found the real lesson in the book, given that the project concerns the provision of an environment in $\mathrm{HE}$ where managers and aspiring managers can learn to discriminate, and courageously navigate the Homeric turbulence of the present age, and contribute towards making a better society. This is tantamount not only to changing the education, but also the socialisation, of managers. In the present age of alternative facts and post-truth, the "current crisis landscape" (Mazza and Strandgaard Pedersen 2015: 356), it is even more incumbent upon educators help turn out managers who are 'educate(d) engage(d), thoughtful citizens' (Örtenblad 2015: 19), able to resist the $\mathrm{FMI}$ as a cure all, and interrogate its promises and the prescriptions for delivery. This is echoed in 
Boselie and Brewster's contribution in Chapter 8 which should be of particular interest to HRM/HRD practitioners, arguing for practitioners to place a stronger focus on the meaning of HR for society as well as the organisation. Practitioners cannot do this without a critical and thinking approach to their practice, something which must be improved in their socialisation and education.

Throughout much of the collection, the role of context, agency and key concepts from the developing field of new institutional theory (see Bohn et al 2015, Chapter 15) help researchers analyse and explain phenomena discovered through an array of organisational research tools. In fact, many chapters are empirical illustrations of the chapter's individual theme, and of themselves interesting examples for students and the teachers alike.

There is a strong social and human progress focus within the collection, such as the contribution of Berthoin Antal in Chapter 18, which engages with the growing predilection bringing the arts into the organisation for learning. Other important themes running through this collection are change, and more productive yet more humane and enlivened workplaces facilitated by inquiring, discriminating, selfless practitioners who can resist the top-down urge to implement an FMI as it is, and who respect the uniqueness of the human infrastructure in the organisation. With this in mind, it is interesting to note that there appears to be little attention to power relations which practitioners will undoubtedly encounter as they attempt to adopt, adapt and contextualise. A contribution on this would have been a welcome addition.

Nevertheless, there is a challenging mix of empirical and theoretical material within this collection, and it is worth the reading effort of a number of stakeholders of FMls. Firstly, the practitioner, interested in how and why FMI enter a context; judicious reading will encourage critical appraisal of what the practitioner is being asked to do. Secondly, educators, who will find rich sources of empirical and theoretical material to share with students, who are the third set of stakeholders of the FMI or panacea. This third set of stakeholders is likely to become practitioners asked to implement FMI, and who will, therefore, be able, as consumers of management knowledge, to make informed and courageous choices.

The chapters in this collection draw on many years of scholarship and different perspectives on these interesting and pervasive phenomena. Given the editorship, and the contributors, there is understandably a Scandinavian 'feel' to the collection, and, therefore, I would advocate this book warmly as the scholarly foundations deserve a wider audience.

I indicated at the beginning of this review that I was fascinated by the prospect of this book and it did not disappoint. This book underscores in bold that many of the FMI discourses do concern people at work. If this volume helps to alter practice among managers, including HRM and HRD managers, and their educators, then this can only be to the good.

\section{References}

Abrahamson E (1996) 'Management fashion', Academy of Management Review 21(1): 254-85

Berthoin Antal A (2015) 'Artistic interventions in organizations: beyond the fad', Chapter 18 in A Örtenblad (ed) Handbook of Research on Management Ideas and Panaceas: Adaptation and Context, Cheltenham, UK: Edward Elgar

Bohn S, Galander A and Walgenbach P (2015) 'The creativity of organizations in taking corporate social responsibility: handling conflicting institutional demands', Chapter 15 in A Örtenblad (ed) Handbook of Research on Management Ideas and Panaceas: Adaptation and Context, Cheltenham, UK: Edward Elgar 
Boselie P and Brewster C (2015) 'The search for panaceas in Strategic Human Resource Management: a wrong turn for HRM research', Chapter 8 in A Örtenblad (ed) Handbook of Research on Management Ideas and Panaceas: Adaptation and Context, Cheltenham, UK: Edward Elgar

Girard R (1988) Deceit, Desire and the Novel, New York: The Athalone Press

Mazza C and Strandgaard Pedersen (2015: 349) 'Good reading makes good action: nothing so practical as a managerial panacea?', Chapter 19 in A Örtenblad (ed) Handbook of Research on Management Ideas and Panaceas: Adaptation and Context, Cheltenham, UK: Edward Elgar

Ohlsson O and Rombach B (2015) 'The art of constructive criticism', Chapter 9 in A Örtenblad (ed) Handbook of Research on Management Ideas and Panaceas: Adaptation and Context, Cheltenham, UK: Edward Elgar

Örtenblad A, Hsu S and Lamb P (2015) 'A stakeholder approach to advising on the relevance of management ideas and panaceas', Chapter 12 in A Örtenblad (ed) Handbook of Research on Management Ideas and Panaceas: Adaptation and Context, Cheltenham, UK: Edward Elgar

Rogers E M (1962) Diffusion of Innovations, New York: Free Press

Rüling C-C (2015) 'Managerial panaceas, sensemaking and identity construction in contemporary organizations', Chapter 24 in A Örtenblad (ed) Handbook of Research on Management Ideas and Panaceas: Adaptation and Context, Cheltenham, UK: Edward Elgar

Whittle R S (2015) 'Changing the story: management panaceas as narrative interventions', Chapter 10 in A Örtenblad (ed) Handbook of Research on Management Ideas and Panaceas: Adaptation and Context, Cheltenham, UK: Edward Elgar

Dr Ruth E Slater FHEA Chartered MCIPD

Senior Lecturer

University of Central Lancashire

reslater@uclan.ac.uk 